\title{
Teaching NeuroImages: Visual loss as a rare complication of mechanical thrombectomy
}

Manuel Bolognese, MD, Alexander von Hessling, MD, and Florian Jordi, MD

Neurology ${ }^{\circledR}$ 2018;90:e355-e356. doi:10.1212/WNL.0000000000004863
Correspondence

Dr. Bolognese

manuel.bolognese@luks.ch

Figure 1 Neuroimaging (digital subtraction angiography, MRI) in acute stroke after middle cerebral artery (MCA) occlusion
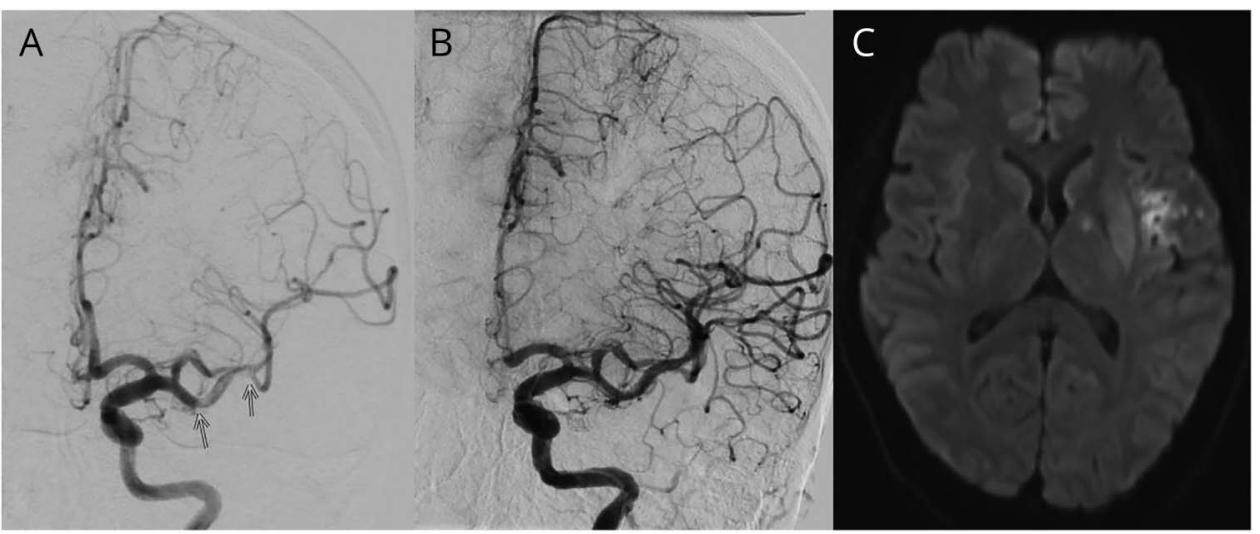

Digital subtraction angiography shows clot in the left MCA before (A, arrows) and complete recanalization after thrombectomy (B). Follow-up diffusion-weighted imaging MRI (C) reveals small infarction in the left MCA territory.
A 46-year-old woman was admitted to the emergency department with a severe left hemispheric syndrome (NIH Stroke Scale [NIHSS] 11). CT showed an occlusion of the left middle cerebral artery, reaching from the distal main trunk (M1) to the inferior division (M2) (figure 1). IV thrombolysis was started and mechanical thrombectomy performed successfully. Postinterventional clinical examination showed mild aphasia (NIHSS 1). However, the patient also complained about impaired ("foggy") vision of the left eye.

Funduscopy showed retinal ischemia of the left eye without any persisting vessel occlusion (figure 2), most likely due to transient thromboembolism as a rare and uncommon complication of thrombectomy. ${ }^{1,2}$

\section{MORE ONLINE}

$\rightarrow$ Teaching slides:

links.lww.com/WNL/A127

Figure 2 Funduscopy

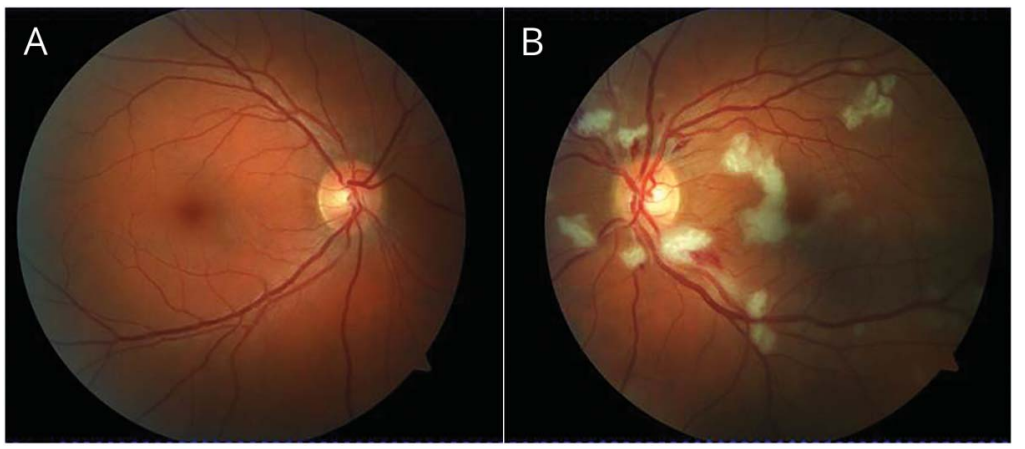

Unremarkable funduscopy of the right eye (A) compared to funduscopy of the left eye (B), which showed retinal hemorrhage and cotton-wool spots as a sign of retinal ischemia.

From the Departments of Neurology (M.B.), Radiology (A.v.H.), and Ophthalmology (F.J.), Cantonal Hospital of Lucerne, Switzerland.

Go to Neurology.org/N for full disclosures. Funding information and disclosures deemed relevant by the authors, if any, are provided at the end of the article. 


\section{Author contributions}

Manuel Bolognese: draft of the manuscript, primary clinical care of the patient. Alexander von Hessling: angiographic images of the patient, clinical care of the patient, revision of the manuscript. Florian Jordi: funduscopic images of the patient, clinical care of the patient, revision of the manuscript.

\section{Study funding}

No targeted funding reported.

\section{Disclosure}

The authors report no disclosures relevant to the manuscript. Go to Neurology.org/ $\mathrm{N}$ for full disclosures.

\section{References}

1. Behme D, Gondecki L, Fiethen S, Kowoll A, Mpotsaris A, Weber W. Complications of mechanical thrombectomy for acute ischemic stroke: a retrospective single-center study of 176 consecutive cases. Neuroradiology 2014;56:467-476.

2. Willinsky RA, Taylor SM, TerBrugge K, Farb RI, Tomlinson G, Montanera W. Neurologic complications of cerebral angiography: prospective analysis of 2,899 procedures and review of the literature. Radiology 2003;227: $522-528$. 


\section{Neurology}

\section{Teaching NeuroImages: Visual loss as a rare complication of mechanical thrombectomy}

Manuel Bolognese, Alexander von Hessling and Florian Jordi

Neurology 2018;90;e355-e356

DOI 10.1212/WNL.0000000000004863

\section{This information is current as of January 22, 2018}

\section{Updated Information \& Services}

References

Subspecialty Collections

Permissions \& Licensing

Reprints including high resolution figures, can be found at: http://n.neurology.org/content/90/4/e355.full

This article cites 2 articles, 0 of which you can access for free at: http://n.neurology.org/content/90/4/e355.full\#ref-list-1

This article, along with others on similar topics, appears in the following collection(s):

\section{All Cerebrovascular disease/Stroke}

http://n.neurology.org/cgi/collection/all_cerebrovascular_disease_strok e

\section{Infarction}

http://n.neurology.org/cgi/collection/infarction

Visual loss

http://n.neurology.org/cgi/collection/visual_loss

Information about reproducing this article in parts (figures,tables) or in its entirety can be found online at:

http://www.neurology.org/about/about_the_journal\#permissions

Information about ordering reprints can be found online:

http://n.neurology.org/subscribers/advertise

Neurology ${ }^{\circledR}$ is the official journal of the American Academy of Neurology. Published continuously since 1951 , it is now a weekly with 48 issues per year. Copyright Copyright @ 2018 American Academy of Neurology. All rights reserved. Print ISSN: 0028-3878. Online ISSN: 1526-632X.

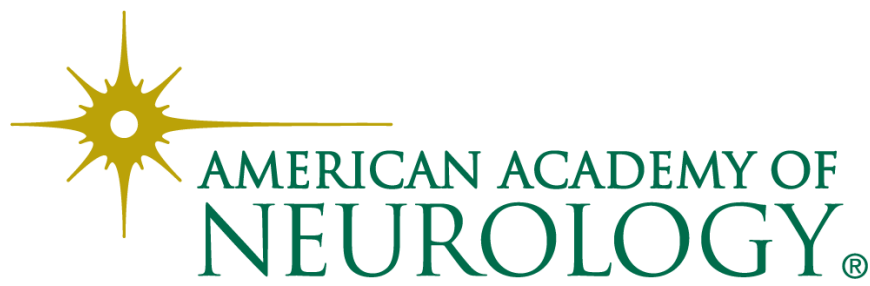

